ISBN $/ 978-93-5137-179-3$

ISSN

$2320-7329$

Ayurlog: National Journal of Reseach in Ayurved Science

\title{
Clinical study of Bastyottar Rasnasaptak Kwath in Trik Graha
}

1. Professor,

2. PG Scholar

Swasthavritta Department, Y.M.T. Ayurvedic Medical College \& Hospital,

Kharghar, Navi- Mumbai -410210.

*Corresponding Author: drsammahajan@gmail.com

\section{Abstract:}

Trik graha is explained in brihat-trayi as well as in other ayurvedic literatures. The patients of Trik graha feel pain at trik sandhi (lumbosacral joint). To reduce this pain, body's own defense mechanism causes spasm of surrounding muscles of lumbosacral joint which reduces its movements. Hence causes stiffness in the joint. In such condition use of analgesic medicines, ointments etc. give temporary relief. Ayurvedic treatment not only reduces the pain but it also helps in complete cure of the disease. For this purpose, 30 diagnosed patients of trik graha were advised yogabasti krama followed by rasnasaptak kwatha $40 \mathrm{ml}$ twice in a day for the period of one month. The observation got are distributed and analyzed statistically. The result showed significant effect of bastyottar use of rasnasaptak kwath in the patients of trik graha.

KEYWORD: Trik graha, basti chikitsa, vata dosha, rasnasaptak kwatha. 


\section{INTRODUTION:}

Maintenance of health of healthy persons and cure of the diseases are the two main objectives of the Ayurveda ${ }^{1}$ One is in perfect health when the Three doshas (Vata, Pitta and Kapha) Digestive fire (jatharagni, sapta-dhatvagni and panchabhutagni) all the body tissues \& components (Sapta-dhatus) (the entire physical body) all the excretory functions (the physiological functions of urination, defecation and sweating) are in perfect order with a pleasantly disposed and contented mind, senses and spirit ${ }^{2}$. Ayurveda has described dinacharya(daily regime), ritucharya(seasonal regime), achara rasayan, sadavritta etc. for the acquisition of Chaturvidha purusartha (dharma, artha, kama, moksha). But in today's era due to lack of such adherence in routine life people came across many diseases. The imbalance state or vitiation of tridoshas is called disease, and its normal state is called health. ${ }^{3}$ According to sharangadhar aacharya, Pitta and Kapha are lame and also are the seven Dhatus. All these are driven by Vayu from place to place like the clouds in the sky by the disturbed wind. Out of the three doshas, Vata is powerful in view of its activating others and putting them to work and this is done by gunas of Vata. ${ }^{4}$ When it gets vitiated it causes different types of diseases called nantamaja vyadhi. There are 80 nanatmaja vyadhi of vata dosha, trik graha is one of them ${ }^{5}$. Excessive consumption of ruksha, shita, laghu anna, alpa annasevan, visham upachar, atilaghan, excessive weight lifting, excessive exercise or labor work, rasadi dhatu kshaya, tension, sorrow, leanness due to any illness, vegadharan, marmaghata, excessive riding on fast vehicles, etc. are the causes of vata $d u s h i^{6}$. In today's lifestyle, due to urbanization and industrialization, person gets busy in his/her work due to which faces many problems regarding health.
Eating such foods or following such lifestyle ultimately gives rise to the vitiation of Vatadi Dosha. Vitiated vata dosha either by obstructive pathology (margavarodha janya) or degenerative pathology (dhatukshyaya janya) causes trik graha. Due to this vata dosha, asthi dhatu gets deprived hence causes pain like trik graha or kati graha.

Aacharya charaka has mentioned basti chikitsa as half treatment ${ }^{7}$. Also basti is the best purification treatment for vata dosha $^{8}$. Hence we decided to give yogabasti krama to the patients as a shodhan chikitsa. As only shodhan chikitsa is not enough for dosha dushti, shaman chikitsa is required. For this purpose selection of Rasnasaptak kwatha was done.

AIM - To study the effect of bastyottar use of rasnasaptak kwath in trik graha

\section{OBJECTIVES -}

1. Literature review of Trik Graha from ayurvedic texts and its correlation with modern pathology

2. Literature review of basti chikitsa from ayurvedic texts

3. To study the effect of basti chikitsa in trik ghraha

4. Literature review of rasnasaptak kwath from ayurvedic texts

5. To study the effect of rasnasaptak $k w a t h$ after basti chikitsa in trik graha

\section{MATERIALS AND METHODS -}

Diagnosed patients of trik graha were first advised yogabasti krama for 8 days followed by rasnasaptak kwath $40 \mathrm{ml}$ twice in day for the period of one month for which following measures were considered.

- In yogabasti karma ${ }^{9}$ - starting with bahya (external) snehan and swedan, anuvasan basti with til tail $120 \mathrm{ml}$ was 
given on first day followed by alternate use of niruha basti (with dashmoola kwatha 480ml+ til tail $240 \mathrm{ml}+$ saindhav 10gm+ madhu 160ml+ kalka 80gm) and anuvasana basti till seventh day. On $8^{\text {th }}$ day, use of anuvasan basti with til tail $120 \mathrm{ml}$ was done.

- Ingredients of Basti

\begin{tabular}{|c|c|c|c|c|c|c|c|}
\hline $\begin{array}{l}\text { Sr. } \\
\text { no }\end{array}$ & Drug name & Latin Name & Rasa & Virya & Vipaka & Guna & Karmukta \\
\hline 1. & Bilwa $^{10}$ & $\begin{array}{l}\text { Aegle } \\
\text { marmelos }\end{array}$ & $\begin{array}{l}\text { Kashaya, } \\
\text { Tikta }\end{array}$ & Ushna & Katu & $\begin{array}{l}\text { Laghu, } \\
\text { Ruksha }\end{array}$ & Kaphavataghna \\
\hline 2. & Agnimantha $^{11}$ & $\begin{array}{l}\text { Clerodendrum } \\
\text { phlomidis }\end{array}$ & $\begin{array}{l}\text { Madhur, } \\
\text { Tikta, }\end{array}$ & Ushna & Katu & $\begin{array}{l}\text { Laghu, } \\
\text { Ruksha }\end{array}$ & Vatakaphaghna \\
\hline 3. & Shyonak $^{12}$ & $\begin{array}{l}\text { Oroxylum } \\
\text { indicum }\end{array}$ & $\begin{array}{l}\text { Madhur, } \\
\text { Tikta, } \\
\text { Kashaya }\end{array}$ & Ushna & Katu & $\begin{array}{l}\text { Laghu, } \\
\text { Ruksha }\end{array}$ & Kaphavataghna \\
\hline 4. & Patala $^{13}$ & $\begin{array}{l}\text { Stereosprmum } \\
\text { sauvealens }\end{array}$ & $\begin{array}{l}\text { Tikta, } \\
\text { Katu }\end{array}$ & Ushna & Katu & Laghu, & Kaphavataghna \\
\hline 5. & Gambhari $^{14}$ & $\begin{array}{l}\text { Gmelina } \\
\text { arborea }\end{array}$ & Katu & Ushna & Katu & Laghu, & Kaphavataghna \\
\hline 6. & Gokshur $^{15}$ & $\begin{array}{l}\text { Tribulus } \\
\text { terrestris }\end{array}$ & Madhur & Shita & Madhur & $\begin{array}{l}\text { Guru, } \\
\text { Deepan }\end{array}$ & Tridoshaghna \\
\hline 7. & Bruhati ${ }^{16}$ & $\begin{array}{l}\text { Solanum } \\
\text { indicum }\end{array}$ & $\begin{array}{l}\text { Katu, } \\
\text { Tikta }\end{array}$ & Ushna & Katu & $\begin{array}{l}\text { Laghu, } \\
\text { Ruksha, } \\
\text { Tikshna }\end{array}$ & Kaphavataghna \\
\hline 8. & Kantakari $^{17}$ & $\begin{array}{l}\text { Solanum } \\
\text { Xanthocarpum }\end{array}$ & $\begin{array}{l}\text { Katu, } \\
\text { Tikta }\end{array}$ & Ushna & Katu & $\begin{array}{l}\text { Laghu, } \\
\text { Ruksha, } \\
\text { Tikshna }\end{array}$ & Kaphavataghna \\
\hline 9. & Prushniparni ${ }^{18}$ & Uraria picta & $\begin{array}{l}\text { Madhur, } \\
\text { Tikta }\end{array}$ & Ushna & Madhur & $\begin{array}{l}\text { Laghu, } \\
\text { Snigdha }\end{array}$ & Tridoshaghna \\
\hline 10. & Shaliparni ${ }^{19}$ & $\begin{array}{l}\text { Desmodium } \\
\text { gangeticum }\end{array}$ & $\begin{array}{l}\text { Madhur, } \\
\text { Tikta }\end{array}$ & Ushna & Madhur & $\begin{array}{l}\text { Laghu, } \\
\text { Snigdha }\end{array}$ & Tridoshaghna \\
\hline 11. & Saidhava $^{20}$ & $\begin{array}{l}\text { Unaqua } \\
\text { Sodium } \\
\text { Chloride }\end{array}$ & Lavana & Ushna & Madhur & $\begin{array}{l}\text { Sigdha, } \\
\text { Tikshna }\end{array}$ & Vatakaphaghna \\
\hline 12. & Madhu $^{21}$ & Honey & $\begin{array}{l}\text { Madhur, } \\
\text { Kashaya }\end{array}$ & Shita & Madhur & $\begin{array}{l}\text { Laghu, } \\
\text { Ruksha }\end{array}$ & Vatakaphaghna \\
\hline 13. & $\begin{array}{l}\text { Til sail }^{22} \\
\text { (sesame oil) }\end{array}$ & $\begin{array}{l}\text { Oil of } \\
\text { Sesamum } \\
\text { indicum }\end{array}$ & $\begin{array}{l}\text { Tikta, } \\
\text { Kashaya }\end{array}$ & Ushna & Madhur & $\begin{array}{l}\text { Guru, } \\
\text { Shukshma }\end{array}$ & Vatakaphaghna \\
\hline
\end{tabular}


- Ingredients of Rasnasaptak kwath ${ }^{23}$

\begin{tabular}{|c|c|c|c|c|c|c|c|}
\hline $\begin{array}{l}\text { Sr. } \\
\text { no }\end{array}$ & Drug name & $\begin{array}{l}\text { Latin } \\
\text { Name }\end{array}$ & Rasa & Virya & Vipaka & Guna & Karmukta \\
\hline 1. & Rasna $^{24}$ & $\begin{array}{l}\text { Alpinia } \\
\text { galangal }\end{array}$ & Tikta & Ushna & Katu & $\begin{array}{l}\text { Guru, } \\
\text { Pachak }\end{array}$ & Kaphavataghna \\
\hline 2. & Gokshur $^{15}$ & $\begin{array}{l}\text { Tribulus } \\
\text { terrestris }\end{array}$ & Madhur & Shita & Madhur & $\begin{array}{l}\text { Guru, } \\
\text { Deepan }\end{array}$ & Tridoshaghna \\
\hline 3. & Erandamool $^{25}$ & $\begin{array}{l}\text { Ricinus } \\
\text { Communis }\end{array}$ & Madhur, Tikta & Ushna & Katu & $\begin{array}{l}\text { Guru, } \\
\text { Vrushya }\end{array}$ & Vatahara \\
\hline 4. & Devadaru $^{26}$ & $\begin{array}{l}\text { Cedrus } \\
\text { deodara }\end{array}$ & Tikta & Ushna & Katu & $\begin{array}{l}\text { Laghu, } \\
\text { Snigdha }\end{array}$ & Kaphavathar \\
\hline 5. & Punarnava ${ }^{27}$ & $\begin{array}{l}\text { Boerhavia } \\
\text { diffusa }\end{array}$ & $\begin{array}{l}\text { Madhur,Tikta, } \\
\text { Kashaya }\end{array}$ & Ushna & Katu & $\begin{array}{l}\text { Laghu, } \\
\text { ruksha }\end{array}$ & Kaphavatahar \\
\hline 6. & Guduchi $^{28}$ & $\begin{array}{l}\text { Tinospora } \\
\text { cordifolia }\end{array}$ & $\begin{array}{l}\text { Tikta, Katu , } \\
\text { Kashay }\end{array}$ & Ushna & Madhur & $\begin{array}{l}\text { Rasayan, } \\
\text { Laghu, } \\
\text { Deepan }\end{array}$ & Tridoshahar \\
\hline 7. & Aragvadha $^{29}$ & $\begin{array}{l}\text { Cassia } \\
\text { fistula }\end{array}$ & Madhur & Shita & Madhur & $\begin{array}{l}\text { Guru, } \\
\text { Sramsana }\end{array}$ & Kaphapittahar \\
\hline 8. & $\begin{array}{l}\text { Shunthi } i^{30} \\
\text { (anupana) }\end{array}$ & $\begin{array}{l}\text { Zinziber } \\
\text { officinalis }\end{array}$ & Katu & Ushna & Madhur & $\begin{array}{l}\text { Guru, } \\
\text { Ruksha, } \\
\text { Tikshna }\end{array}$ & Kaphavatahar \\
\hline
\end{tabular}

Preparation of Rasnasaptak Kwatha The Kwatha was prepared freshly every time as per procedure described in Sharangdhara Samhita ${ }^{31}$.

\section{Drug standardisation -}

Authentification \& standardisation of raw materials was done under guidance of experts of Dravyaguna and Rasashastra department of the institute and external entity.

Study type - An open non-comparative prospective clinical study

No. of patients - 30

Source of data - Total 30 patients were selected randomly from OPD \& IPD units. Clinical trial was carried out on patients suffering from Trik graha. These data were subjected to statistical analytical methods and on the basis of which a conclusion was drawn, specifying the efficiency of 'Bastyottar Rasnasaptak $k$ wath' under trial.

Consent - An informed written consent of all patients was taken before treatment.

\section{Diagnostic criteria -}

As the symptoms of trik graha are not clearly mentioned in samhitas. Following few symptoms are drawn from common symptoms of vata dosha as well as from practical experience. Patients were selected on the basis of subjective criteria mentioned below.

1. Katishoola

2. Stabdhata

3. Akunchan samayi vedana

4. Prasarana samayi vedana

5. Paad pipilikavat vedana

6. Supti

7. Adhman

8. Malavshthambhaka

\section{Inclusion criteria}


1. Patients aged between 21 years to 60 years of either sex.

2. Diagnose patients of trik graha and suitable for basti chikitsa

\section{Exclusion criteria}

1. Patients with diabetes, fracture and cancer

2. Patients with scoliosis, lordosis and kyphosis

3. Patients unsuitable for basti chikitsa

4. Pregnant and lactating women

\section{Investigations -}

\section{Subjective criteria -}

\begin{tabular}{|c|c|c|c|}
\hline \multirow[t]{4}{*}{1.} & \multirow[t]{4}{*}{ Kati shoola } & Absent & $\mathbf{0}$ \\
\hline & & Mild pain & + \\
\hline & & $\begin{array}{l}\text { Moderate pain- } \\
\text { difficulty in walking }\end{array}$ & ++ \\
\hline & & $\begin{array}{l}\text { Severe pain- difficulty in } \\
\text { walking }\end{array}$ & +++ \\
\hline 2. & Stabdhata & Free movements & $\mathbf{0}$ \\
\hline & & Mild painful movements & + \\
\hline & & $\begin{array}{l}\text { Difficult and painful } \\
\text { movements }\end{array}$ & ++ \\
\hline & 10 & No free movements & +++ \\
\hline 3. & Aakunchan kriya samayi vedana & Painless & $\mathbf{0}$ \\
\hline & 3 & $\begin{array}{l}\text { Mild painful with no facial } \\
\text { expression }\end{array}$ & + \\
\hline & & $\begin{array}{l}\text { Moderate pain with facial } \\
\text { expression }\end{array}$ & ++ \\
\hline & & No flexion movements & +++ \\
\hline 4. & Prasaran kriya samayi vedana & Painless & $\mathbf{0}$ \\
\hline & & $\begin{array}{l}\text { Mild painful with no facial } \\
\text { expression }\end{array}$ & + \\
\hline & & $\begin{array}{l}\text { Mild painful with no facial } \\
\text { expression }\end{array}$ & ++ \\
\hline & & No extension movements & +++ \\
\hline 5. & Paad pipilikavat sanchar & Absent & $\mathbf{0}$ \\
\hline & & $\begin{array}{l}\text { Increases with extreme } \\
\text { walking/ sitting }\end{array}$ & + \\
\hline & & $\begin{array}{lll}\begin{array}{l}\text { Increases with flexion/ } \\
\text { extension }\end{array} & & \\
\end{array}$ & ++ \\
\hline & & Always present & +++ \\
\hline 6. & Supti & Absent & $\mathbf{0}$ \\
\hline & & Increases with long time & + \\
\hline
\end{tabular}

- $\mathrm{CBC}$

- Urine routine and microscopic

- X-ray Lumbo-sacral joint AP \& Lateral view

\begin{tabular}{|l|l|}
\hline Dose of kwatha & $40 \mathrm{ml}$ \\
\hline $\begin{array}{l}\text { Route of } \\
\text { administration }\end{array}$ & Orally \\
\hline Kala & $\begin{array}{l}\text { Twice in a day } \\
\text { after food }\end{array}$ \\
\hline Anupana & $\begin{array}{l}\text { Shunthi churna } \\
\text { (prakshep } \\
\text { dravya) }\end{array}$ \\
\hline
\end{tabular}




\begin{tabular}{|c|c|c|c|}
\hline & & sitting & \\
\hline & & $\begin{array}{lll}\text { Always } & \text { present } & \text { but } \\
\text { bearable } & & \end{array}$ & ++ \\
\hline & & $\begin{array}{lll}\begin{array}{l}\text { Always present } \\
\text { unbearable }\end{array} & \text { and }\end{array}$ & +++ \\
\hline \multirow[t]{4}{*}{7.} & Adhama & Absent & $\mathbf{0}$ \\
\hline & & $\begin{array}{l}\text { Present after one hour of } \\
\text { food }\end{array}$ & + \\
\hline & & $\begin{array}{l}\text { Present immediately after } \\
\text { food }\end{array}$ & ++ \\
\hline & & Always present & +++ \\
\hline \multirow[t]{4}{*}{8.} & Malavashthambha & Absent & $\mathbf{0}$ \\
\hline & & $\begin{array}{l}\text { Once in a day but } \\
\text { unsatisfactory }\end{array}$ & + \\
\hline & & $\begin{array}{l}\text { Once in a day with the use } \\
\text { of mild purgative }\end{array}$ & ++ \\
\hline & & $\begin{array}{l}\text { Once in a day with the use } \\
\text { of strong purgative }\end{array}$ & +++ \\
\hline
\end{tabular}

OBSERVATION AND RESULT -

1. Classification by age

\begin{tabular}{|l|l|l|}
\hline Age (in yrs) & Total no. of pts & Percentage \\
\hline $21-30$ & 2 & $6.66 \%$ \\
\hline $31-40$ & 5 & $16.66 \%$ \\
\hline $41-50$ & 14 & $46.66 \%$ \\
\hline $51-60$ & 7 & $23.33 \%$ \\
\hline $61-70$ & 2 & 6.66 \\
\hline
\end{tabular}

2. Classification by gender

\begin{tabular}{|l|l|l|}
\hline Gender & No. of pts & Percentage \\
\hline Males & 23 & $76.66 \%$ \\
\hline Females & 7 & 26.33 \\
\hline
\end{tabular}

\section{Classification by Occupation}

\begin{tabular}{|l|l|l|}
\hline Occupation & No. of Pts & Percentage \\
\hline Housewives & 7 & $23.33 \%$ \\
\hline Standing job, hard-work & 15 & $50 \%$ \\
\hline Sitting job & 8 & 26.66 \\
\hline
\end{tabular}


4. Classification according to weight

\begin{tabular}{|l|l|l|}
\hline Wt in kgs & No. of Pts & Percentage \\
\hline $31-40$ & 1 & $3.33 \%$ \\
\hline $41-50$ & 1 & $3.33 \%$ \\
\hline $51-60$ & 13 & $43.33 \%$ \\
\hline $61-70$ & 12 & $40.00 \%$ \\
\hline $71-80$ & 3 & $10.00 \%$ \\
\hline
\end{tabular}

5. Classification according to chronocity

\begin{tabular}{|l|l|l|}
\hline Chronicity & No. of Pts & Percentage \\
\hline Since 1 year & 9 & $30.00 \%$ \\
\hline From 1-2 years & 7 & $23.33 \%$ \\
\hline From 2-5 years & 7 & $23.33 \%$ \\
\hline From more than 5 years & 7 & 23.33 \\
\hline
\end{tabular}

\begin{tabular}{|c|c|c|c|c|c|}
\hline Symptoms & Treatment & Days & Mean (x) & 't' value & 'p' value \\
\hline \multirow[t]{6}{*}{ Katishoola } & \multirow[t]{4}{*}{ Basti } & 0 & 2.46 & & \\
\hline & & 3 & 2.46 & & \\
\hline & & 6 & 2.06 & 4.44 & $<0.001$ \\
\hline & & 8 & 1.73 & 6.63 & $<0.001$ \\
\hline & \multirow[t]{2}{*}{$\begin{array}{l}\text { Rasnasaptak } \\
\text { kwath }\end{array}$} & 15 & 1.50 & 14.92 & $<<0.001$ \\
\hline & & 30 & 1.00 & 16.33 & $<<0.001$ \\
\hline \multirow[t]{6}{*}{ Stabdhata } & \multirow[t]{4}{*}{ Basti } & 0 & 1.8 & & \\
\hline & & 3 & 1.8 & & \\
\hline & & 6 & 1.7 & 2 & $<0.05$ \\
\hline & & 8 & 1.5 & 3.75 & $<0.001$ \\
\hline & \multirow{2}{*}{$\begin{array}{l}\text { Rasnasaptak } \\
\text { kwath }\end{array}$} & 15 & 1.06 & 7.3 & $<0.001$ \\
\hline & & 30 & 0.93 & 9.66 & $<<0.001$ \\
\hline \multirow{6}{*}{$\begin{array}{l}\text { Akunchan } \\
\text { samayi vedana }\end{array}$} & \multirow[t]{4}{*}{ Basti } & 0 & 1.73 & & \\
\hline & & 3 & 1.73 & & \\
\hline & & 6 & 1.57 & 2.14 & $<0.05$ \\
\hline & & 8 & 1.38 & 3.88 & $<0.001$ \\
\hline & \multirow{2}{*}{$\begin{array}{l}\text { Rasnasaptak } \\
\text { kwath }\end{array}$} & 15 & 1.04 & 7.66 & $<0.001$ \\
\hline & & 30 & 0.92 & 10.25 & $<<0.001$ \\
\hline \multirow{6}{*}{$\begin{array}{l}\text { Prasaran } \\
\text { vedana }\end{array}$} & \multirow[t]{4}{*}{ Basti } & 0 & 1.85 & & \\
\hline & & 3 & 1.85 & & \\
\hline & & 6 & 1.54 & 3.44 & $<0.01$ \\
\hline & & 8 & 1.42 & 4.8 & $<0.001$ \\
\hline & \multirow{2}{*}{$\begin{array}{l}\text { Rasnasaptak } \\
\text { kwath }\end{array}$} & 15 & 1.38 & 5.6 & $<0.001$ \\
\hline & & 30 & 1.38 & 5.6 & $<0.001$ \\
\hline \multirow[t]{2}{*}{ Adhmana } & \multirow[t]{2}{*}{ Basti } & 0 & 1.50 & & \\
\hline & & 3 & 1.33 & & \\
\hline
\end{tabular}




\begin{tabular}{|c|c|c|c|c|c|}
\hline & & 6 & 0.83 & 4.44 & $<0.001$ \\
\hline & & 8 & 0.41 & 6.63 & $<0.001$ \\
\hline & \multirow{2}{*}{$\begin{array}{l}\text { Rasnasaptak } \\
\text { kwath }\end{array}$} & 15 & 0.25 & 14.92 & $<<0.001$ \\
\hline & & 30 & 1.00 & 16.33 & $<<0.001$ \\
\hline \multirow{6}{*}{$\begin{array}{l}\text { Paad } \quad \text { pipilikavat } \\
\text { sanchar }\end{array}$} & \multirow[t]{4}{*}{ Basti } & 0 & 1.73 & & \\
\hline & & 3 & 1.73 & & \\
\hline & & 6 & 1.53 & 0.00 & $<0.05$ \\
\hline & & 8 & 1.13 & 4.61 & $<0.001$ \\
\hline & \multirow{2}{*}{$\begin{array}{l}\text { Rasnasaptak } \\
\text { kwath }\end{array}$} & 15 & 1.00 & 5.07 & $<0.001$ \\
\hline & & 30 & 0.86 & 13.28 & $<<0.001$ \\
\hline \multirow[t]{6}{*}{ Malavasthambha } & \multirow[t]{4}{*}{ Basti } & 0 & 1.5 & & \\
\hline & & 3 & 1.14 & 2.35 & $<0.01$ \\
\hline & & 6 & 0.36 & 5.42 & $<0.01$ \\
\hline & & 8 & 0.00 & 8.41 & $<0.001$ \\
\hline & \multirow{2}{*}{$\begin{array}{l}\text { Rasnasaptak } \\
\text { kwath }\end{array}$} & 15 & 0.21 & 7.5 & $<0.001$ \\
\hline & & 30 & 0.00 & 10.71 & $<<0.001$ \\
\hline
\end{tabular}

DISCUSSION - Vata is described as a beholder of yantra and also the tantra ${ }^{32}$. Yantra is the

whole body machine. Tantra is the controlling mechanism of whole body organization comprising of seventy trillion cells. The Vata Dosha, when it is normal, sustains the functioning of all the organs of the body. And its vitiated state, it causes various samanya (jwar, raktapitta, etc.) and asamanya (nanatmaja vyadi) diseases in the body ${ }^{33}$. Trik graha is one of the nanatmaja vikar of Vata dosha mentioned in Ayurveda.

Basti therapy is defined as the most powerful and effective procedures of Panchakarma. It is stated in Ayurved that most of the diseases are caused by imbalance of vata dosha and basti is called 'Ardha Chikitsa', because of the concept that it cures half of the diseases of the body $^{7}$. Basti treatments balance and nurture the vata dosha. When basti is used in conjunction with the pre-procedures of Panchakarma, it cleans far more than just the colon (pakvashaya). This therapy helps in purifying the toxins from all over the body. The nutritive and the palliative qualities of basti therapy address all the functional factors of colon. In addition to getting rid of the toxins, it also helps in restoring the healthy functions to the colon and through the colon it nurtures and rebuilds the tissues and organs. Basti therapy is actually the most effective treatment for disorders that are arising from abnormal vata ${ }^{34}$.

Sesame oil (til tail) is the main base oil used in most of ayurvedic oils. Here it was used for Anuvasana basti. Of all the varieties of oil, sesame oil is best for improving strength and imparting oiliness to the body, hence said to be the best Vata shamaka. It balances Vata and Kapha dosha, slightly increases pitta dosha. Improves digestive power, clear and cleanses body channels. It is having antiaging and rejuvenating properties too ${ }^{22}$.

Dashamoola is tidosha nashaka and balances Vata, Pitta and Kapha. It is excellent medicine for treating Vata vyadhi. It reduces inflammation and pain. It is such an intelligent blend of medicinal herbs that balances all the three doshas. It improves digestive power also digest toxins of body (aam pachak), alleviates or prevents rheumatism, acting to relieve pain, improves well-being ${ }^{35-37}$.

Rasnasaptak kwatha is the polyherbal medicine mentioned in 
bhavprakasha samhita vatavyadhi adhikar. It contains Rasna and other seven ingredients and hence named Rasnasaptak Kwatha. The medicinal herbs used in this formulation are Tridoshnasak. This medicine is having shothahara and shoolahara properties and it is used in Janghashula, Urushula, Parshva Shula, Trika Shula, Prishtha Shula. Rasna is Tikta, Guru, Ushna and Katu vipak. It pacifies Kapha and Vata. Rasna root is fragrant, bitter and useful in rheumatism and other inflammatory disorders. Its stem, leaves are muscle relaxant. Along with other herbal ingredients the roots are useful in all nervous diseases and joint disorders. Guduchi gives relief in pain and inflammation. It is a Rasayan drug of Ayurveda. It has positive influence on whole health. Devdaru has analgesics and anti-inflammatory action. It pacifies Vata dosha hence reduces the pain. Gokshur improves digesion, strength, nourishes the body, removes kleda out of body hence cleanses the body. Punarnava is diuretic and helps to reduce swelling by losing extra fluid from body.italsoreduces the pain. Erandamool and Aragvadha support proper bowel evacuation and removal of waste from body due to their purgative action. They help to cure bloating and constipation $^{23-30}$.

\section{CONCLUSION -}

1. Trik graha is the nanatmaja vyadhi of vata dosha caused due to vitiation of vata.

2. Basti is mainly advised in the treatment of vata dosha vitiation along with shaman chikitsa. Hence in Trik Graha we first used basti chikitsa as shodhan karma followed by rasnasaptak kwatha as shaman chikitsa for the period of one month.

3. Causes of vata vyadhi are mentioned in ayurvedic texts. From which following causes are found more in patients of Trik graha Ruksha, shita annapan, virodhi annapan, alpashana, atyadhik bhar vahan, vishamasha, excessive travelling on fast vehicles, long standing, bending work or sitting work pattern, accident, postoperative complications, old age.

4. Stabdhata and katishoola symptoms are found in all the patients of trik graha whereas flexion and extension difficulties were found in 26 and 25 patients respectively.

5. Patients with Symptoms like Adhmana and malavashthambha got maximum relief only by basti chikitsa.

6. Trik graha is mainly caused due to vitiation of vata dosha but along with that we also found asthi dhatu ,majja dhatu as well as asthivaha srotas and majjavaha srotas dushti in it.

7. This disease was mainly found in the patients with physical hard work, long standing or sitting jobs.

8. The effect of basti chikitsa and rasnasaptak kwatha gave excellent results in the patients of trik graha which proves its safety and efficacy in it. Hence it opens the new door for ayurvedic practice and helps to treat nanatmaj vyadhi of vata dosha like Trik graha.

\section{REFERENCES -}

1. Prof. R. H. Singh, charak samhita of agnivesh elaborated by charaka and dridhbala edited by vaidya yadavji trikamji, ayurved dipika commentary by shree chakrapanidatta, sutra sthana, chapter $30^{\text {th }}$, verse 26 , edition 2014 , chaukhaba surbharati prakashana, Varanasi, page no. 187

2. Dr. Anantram Sharma, Sushrut samhita of maharshi sushruta edited with sushruta vimarshini hindi commentary, vol 1 , sutra sthana, chapter $15^{\text {th }}$, verse 47, edition 2013, chaukhamba 
surbharti prakashan, Varanasi, page no. 130

3. Dr. Bhramhananda tripathi, Asthanga hridaya of shrimda vagbhata edited with nirmala hindi commentary, sutra sthana, chapter $1^{\text {st }}$, verse 20 , edition 2015, chaukhamba sanskrita pratisthana, delhi, page no. 16

4. Prof. C. B. Jha, Sharangadhar samhita of shri sharangadharacharya, adhamalla's dipika \& kashiram's gudhartha dipika, prathama khanda, chapter $5^{\text {th }}$, verse 25 , edition 2006 , chaukhamba surbharti prakashan, Varanasi, page. no. 50

5. Prof. R. H. Singh, charak samhita of agnivesh elaborated by charaka and dridhbala edited by vaidya yadavji trikamji, ayurved dipika commentary by shree chakrapanidatta, sutra sthana, chapter $20^{\text {th }}$, verse 11 , edition 2014 , chaukhaba surbharati prakashana, Varanasi, page no. 113

6. Prof. R. H. Singh, charak samhita of agnivesh elaborated by charaka and dridhbala edited by vaidya yadavji trikamji, ayurved dipika commentary by shree chakrapanidatta, chikitsa sthana, chapter $28^{\text {th }}$, verse 15-18, edition 2014, chaukhaba surbharati prakashana, Varanasi, page no. 617

7. Prof. R. H. Singh, charak samhita of agnivesh elaborated by charaka and dridhbala edited by vaidya yadavji trikamji, ayurved dipika commentary by shree chakrapanidatta, siddhi sthana, chapter $1^{\text {st }}$, verse 40 , edition 2014, chaukhaba surbharati prakashana, Varanasi, page no. 683

8. Dr. Bhramhananda tripathi, Asthanga hridaya of shrimda vagbhata edited with nirmala hindi commentary, sutra sthana, chapter $1^{\text {st }}$, verse $25-26$, edition 2015, chaukhamba sanskrita pratisthana, delhi, page no. 20

9. Dr. Bhramhananda tripathi, Asthanga hridaya of shrimda vagbhata edited with nirmala hindi commentary, sutra sthana, chapter $19^{\text {th }}$, verse $64-65$, edition 2015, chaukhamba sanskrita pratisthana, delhi, page no. 130

10. Dr. G. S. Pandey, bhavprakasha nighantu of bhavmishra edited by Dr. K. C. Chunekar, hindi commentary, guduchyadi gana, verse 13 , edition 2002, chaukhamba bharati academy, Varanasi,page no. 274

11. Dr. G. S. Pandey, bhavprakasha nighantu of bhavmishra edited by Dr. K. C. Chunekar, hindi commentary, guduchyadi gana, verse 23-24, edition 2002, chaukhamba bharati academy, Varanasi,page no. 281

12. Dr. G. S. Pandey, bhavprakasha nighantu of bhavmishra edited by Dr. K. C. Chunekar, hindi commentary, guduchyadi gana, verse 25-26, edition 2002, chaukhamba bharati academy, Varanasi,page no. 283

13. Dr. G. S. Pandey, bhavprakasha nighantu of bhavmishra edited by Dr. K. C. Chunekar, hindi commentary, guduchyadi gana, verse 21 , edition 2002, chaukhamba bharati academy, Varanasi,page no. 278

14. Dr. G. S. Pandey, bhavprakasha nighantu of bhavmishra edited by Dr. K. C. Chunekar, hindi commentary, guduchyadi gana, verse 14-16, edition 2002, chaukhamba bharati academy, Varanasi,page no. 276

15. Dr. G. S. Pandey, bhavprakasha nighantu of bhavmishra edited by Dr. K. C. Chunekar, hindi commentary, guduchyadi gana, verse 44-46, edition 2002, chaukhamba bharati academy, Varanasi,page no. 292

16. Dr. G. S. Pandey, bhavprakasha nighantu of bhavmishra edited by Dr. K. C. Chunekar, hindi commentary, guduchyadi gana, verse 36-37, edition 2002, chaukhamba bharati academy, Varanasi,page no. 288

17. Dr. G. S. Pandey, bhavprakasha nighantu of bhavmishra edited by Dr. K. C. Chunekar, hindi commentary, guduchyadi gana, verse 40-41, edition 2002, chaukhamba bharati academy, Varanasi,page no. 290 
18. Dr. G. S. Pandey, bhavprakasha nighantu of bhavmishra edited by Dr. K. C. Chunekar, hindi commentary, guduchyadi gana, verse $34-35$, edition 2002, chaukhamba bharati academy, Varanasi,page no. 286

19. Dr. G. S. Pandey, bhavprakasha nighantu of bhavmishra edited by Dr.

K. C. Chunekar, hindi commentary, guduchyadi gana, verse 31-33, edition 2002, chaukhamba bharati academy, Varanasi,page no. 285

20. Prof. R. H. Singh, charak samhita of agnivesh elaborated by charaka and dridhbala edited by vaidya yadavji trikamji, ayurved dipika commentary by shree chakrapanidatta, sutra sthana, chapter $1^{\text {st }}$, verse 89 , edition 2014 , chaukhaba surbharati prakashana, Varanasi, page no. 21

21. Dr. G. S. Pandey, bhavprakasha nighantu of bhavmishra edited by Dr. K. C. Chunekar, hindi commentary, madhu varga, verse 1-5, edition 2002, chaukhamba bharati academy, Varanasi,page no. 988

22. Dr. G. S. Pandey, bhavprakasha nighantu of bhavmishra edited by Dr.

K. C. Chunekar, hindi commentary, tail varga, verse 2-6, edition 2002, chaukhamba bharati academy, Varanasi,page no. 779

23. Prof. K. R. Srikantha murthy, bhavaprakasha of bhavamishra, volume 2 , chapter $24^{\text {th }}$, verse 144 , edition 2002, krishnadas academy, Varanasi, page no. 333

24. Dr. G. S. Pandey, bhavprakasha nighantu of bhavmishra edited by Dr. K. C. Chunekar, hindi commentary, haritakyadi gana, verse 162-164, edition 2002, chaukhamba bharati academy, Varanasi,page no. 79

25. Dr. G. S. Pandey, bhavprakasha nighantu of bhavmishra edited by Dr. K. C. Chunekar, hindi commentary, guduchyadi gana, verse 60-66, edition 2002, chaukhamba bharati academy, Varanasi,page no. 299
26. Dr. G. S. Pandey, bhavprakasha nighantu of bhavmishra edited by Dr. K. C. Chunekar, hindi commentary, karpuradi gana, verse 24-25, edition 2002, chaukhamba bharati academy, Varanasi,page no. 196

27. Dr. G. S. Pandey, bhavprakasha nighantu of bhavmishra edited by Dr. K. C. Chunekar, hindi commentary, guduchyadi gana, verse 231-233, edition 2002, chaukhamba bharati academy, Varanasi,page no. 421

28. Dr. G. S. Pandey, bhavprakasha nighantu of bha2vmishra edited by Dr. K. C. Chunekar, hindi commentary, guduchyadi gana, verse 6-10, edition 2002, chaukhamba bharati academy, Varanasi,page no. 269

29. Dr. G. S. Pandey, bhavprakasha nighantu of bhavmishra edited by Dr. K. C. Chunekar, hindi commentary, haritakyadi gana, verse 148-150, edition 2002, chaukhamba bharati academy, Varanasi,page no. 68

30. Dr. G. S. Pandey, bhavprakasha nighantu of bhavmishra edited by Dr. K. C. Chunekar, hindi commentary, haritakyadi gana, verse 44-48, edition 2002, chaukhamba bharati academy, Varanasi,page no. 12

31. Prof. C. B. Jha, Sharangadhar samhita of shri sharangadharacharya, adhamalla's dipika \& kashiram's gudhartha dipika, madhyama khanda, chapter $2^{\text {nd }}$, verse 1 , edition 2006, chaukhamba surbharti prakashan, Varanasi, page. no. 144

32. Prof. R. H. Singh, charak samhita of agnivesh elaborated by charaka and dridhbala edited by vaidya yadavji trikamji, ayurved dipika commentary by shree chakrapanidatta, sutra sthana, chapter $12^{\text {th }}$, verse 8 , edition 2014 , chaukhaba surbharati prakashana, Varanasi, page no.79

33. Prof. R. H. Singh, charak samhita of agnivesh elaborated by charaka and dridhbala edited by vaidya yadavji trikamji, ayurved dipika commentary by shree chakrapanidatta, sutra sthana, 
chapter $20^{\text {th }}$, verse 10 , edition 2014 , chaukhaba surbharati prakashana, Varanasi, page no. 113

34. Prof. R. H. Singh, charak samhita of agnivesh elaborated by charaka and dridhbala edited by vaidya yadavji trikamji, ayurved dipika commentary by shree chakrapanidatta, siddhi sthana, chapter $1^{\text {st }}$, verse $32-34$, edition 2014, chaukhaba surbharati prakashana, Varanasi, page no. 683

35. Dr. G. S. Pandey, bhavprakasha nighantu of bhavmishra edited by Dr. K. C. Chunekar, hindi commentary, guduchyadi gana, verse 29-30, edition
2002, chaukhamba bharati academy, Varanasi,page no. 285

36. Dr. G. S. Pandey, bhavprakasha nighantu of bhavmishra edited by Dr. K. C. Chunekar, hindi commentary, guduchyadi gana, verse 47-48, edition 2002, chaukhamba bharati academy, Varanasi,page no. 294

37. Dr. G. S. Pandey, bhavprakasha nighantu of bhavmishra edited by Dr. K. C. Chunekar, hindi commentary, guduchyadi gana, verse 49 , edition 2002, chaukhamba bharati academy, Varanasi,page no. 294

\section{Cite this article:}

Clinical study of Bastyottar Rasnasaptak Kwath in Trik Graha

Sameer S. Mahajan, Rekha Zala

Ayurlog: National Journal of Research in Ayurved $S_{\text {cience-2017; 6(1): 1-12 }}$ 